\title{
CLOSING THE GAP FOR PHARMACOLOGICAL TREATMENT OF PAINFUL DIABETIC NEUROPATHY : THE POTENTIAL ROLE OF VITAMIN D
}

\author{
Rizaldy Taslim Pinzon ${ }^{1,2}$, Angela ${ }^{1,2}$ \\ Correspondence: drpinzon17@gmail.com \\ ${ }^{1}$ Neurology Department, Duta Wacana Christian University School of Medicine Yogyakarta, Indonesia \\ ${ }^{2}$ Bethesda Hospital Yogyakarta, Indonesia
}

Article History:

Received: June 3, 2021

Accepted: November 22, 2021

Published: January 1, 2022

\section{Cite this as:}

Pinzon RT Angela A. Closing the gap for pharmacological

treatment of painful diabetic neuropathy : the potential role of vitamin D. Malang Neurology Journal; 2022.8:49-52. DOI: http://dx.doi.org/10.21776/ub.mnj .2022 .008 .01 .10

\section{ABSTRACT}

Painful neuropathic pain is a challenging chronic pain to treat. It is heterogeneous in symptoms and could be resistant to the available treatments regimen. Current pharmacological treatments fail to achieve adequate pain relief in a most patients. The previous review showed that only less than 50\% of patients can achieve good pain reduction with standard adjuvant treatment. The available adjuvants analgesic only focus in the symptom control, and do not interfere with the progressing damage of the nerve. Vit $\mathrm{D}$ insufficiency is quite frequent in type 2 diabetes patients.diabetes, particularly those with symptoms of DPN. The studies also showed that low serum vitamin D levels are an independent predictor of DPN development. Vitamin D supplementation is necessary for diabetic neuropathy patients since it promotes the synthesis of neurotrophins and neurotransmitters. Additional vitamin D therapy have big role in nerve growth factor and the regulation of neurotrophin and $\mathrm{Ca}^{2+}$ homeostasis in neurons, and provides protection for neurons in the peripheral nervous system. In this review, we do systematically search the studies about Vitamin D for the treatment of painful diabetic neuropathic condition. We used PubMed, Cochrane, Clinical Key, and search Google Scholar for papers that used vitamin D phrases. and painful diabetic neuropathy as our major database for this review and we make a systematic table to explain our review. However, there is still an unmet need in the management of neuropathic pain. The unmet needs maybe caused by the gap between pharmacological treatmnet in pain reduction in painful diabetic neuropathy patients. Therefore, in this review we discuss about the potential use of vitamin D as an add-on therapy to closing the gap in the management of neuropathic pain.

Keywords: Painful diabetic neuropathy, vitamin D, treatment

\section{Introduction}

Diabetes is among the most serious health diseases in the world, with an annual rise of $5 \%$ in the number of incidents. ${ }^{1}$ The International Diabetes Federation states that the number of individuals living with diabetes surpassed 425 million in 2017 and is predicted to rise to 628 million by $2045 .^{2}$ Painful Diabetic Neuropathy (PDN) is the most frequent diabetic consequence, afflicting $90 \%$ of patients. ${ }^{3}$ Hypesthesia or paresthesia of both symmetrical limbs, stabbing pain, scorching, and numbness are some symptoms of PDN, which might affect one's quality of life. ${ }^{4}$ Numerous research have discovered several treatment possibilities for dealing with pain in PDN, but the findings aren't as promising owing to the disease's unknown pathophysiology and the drug's restrictions in terms of administration due to polypharmaceutical adverse effects. ${ }^{5}$ Diabetic neuropathies can be caused by a variety of conditions, including metabolic and vascular issues, as well as Reactive Oxygen Species (ROS). ${ }^{4}$

A glycemic index arrangement, for example, is one of the treatment choices that may be used. pain management, symptomatic medication, and foot care are the most common treatments. ${ }^{3,4}$ Based on guidelines, several drug therapies that recommended for PDN. They are anticonvulsants, pregabalin, and gabapentin until the pain subsides. ${ }^{6}$ However, this medication only addresses the manifestations of current pain, not the underlying pathophysiological causes or the sensory abnormalities shown in neuropathy studies. ${ }^{5}$ To reduce apoptosis, oxidative stress, and neuronal inflammation, multi-target therapies are required.,7 Further treatment may be a possibility to help with recovery and metabolism pathology, which happens when the body's glycemic index rises, causing the hexosamine pathway to operate and induce the incidence of reactive oxygen species (ROS) and inflammatory. ${ }^{6,7}$

Previous studies showed that Vitamin D insufficiency was common among diabetes individuals with peripheral neuropathy. Low vitamin levels are more common in females and people with chronic neuropathic. ${ }^{8,9}$ 
Table 1. The benefit of vitamin D for painful diabetic neuropathy

\begin{tabular}{|c|c|c|c|}
\hline Author & Method & Subject & Result \\
\hline $\begin{array}{l}\text { Shehab.D, et al, } \\
2015^{12}\end{array}$ & $\begin{array}{l}\text { Non-random, } \\
\text { double blind, } \\
\text { placebo- } \\
\text { controlled } \\
\text { clinical trial }\end{array}$ & $\begin{array}{l}112 \text { people with diabetic neuropathy } \\
\text { and vitamin } D \text { deficiency. } \\
8 \text { weeks with intervention of oral } \\
\text { vitamin } \mathrm{D}_{3} \text { (cholecalsiferol } 50000 \\
\text { IU). }\end{array}$ & $\begin{array}{l}\text { There was significant increase in concentrations } \\
\text { serum of } 25(\mathrm{OH}) \mathrm{D}(1.1 \pm 3.6 \text { vs } 32.8 \pm 23.7, \mathrm{p} \\
<0.0001) \text {. } \\
\text { There was increase in the NSS (neuropathy } \\
\text { symptom score) in the treatment group }(-0.20 \pm \\
0.59 \text { vs }-1.49 \pm 1.37 \mathrm{p}<0.001)\end{array}$ \\
\hline $\begin{array}{l}\text { Alam. U, et al, } \\
2017^{13}\end{array}$ & $\begin{array}{l}\text { Open label } \\
\text { clinical trial }\end{array}$ & $\begin{array}{l}143 \text { participants with diabetic } \\
\text { neuropathy pain }\end{array}$ & $\begin{array}{l}\text { Vitamin D treatment increased 25(OH)D D levels } \\
\text { significantly ( } \mathrm{p} 0.0001) \text { and improved the } \\
\text { NeuroQoL level for emotional discomfort ( } \mathrm{p}= \\
0.04) \text {. }\end{array}$ \\
\hline $\begin{array}{l}\text { Nadi.M, et al, } \\
2017^{14}\end{array}$ & $\begin{array}{l}\text { Clinical Trial } \\
\text { Study }\end{array}$ & $\begin{array}{l}81 \text { women aged } 20-55 \text { years with type } \\
2 \text { diabetes without comorbid }\end{array}$ & $\begin{array}{l}\text { Vitamin D supplementation reduce weakness }(\mathrm{p}= \\
0.005) \text {, tingling }(\mathrm{p}=0.001) \text {, pain }(\mathrm{p}=0.002) \text {, and } \\
\text { numbness }(\mathrm{p}=0.001),\end{array}$ \\
\hline $\begin{array}{l}\text { Ghadiri-Anari et } \\
\text { al, } 2019^{15}\end{array}$ & $\begin{array}{l}\text { Before-after } \\
\text { trial }\end{array}$ & $\begin{array}{l}58 \text { diabetic neuropathy patients aged } \\
30-65 \text { years }\end{array}$ & $\begin{array}{l}\text { Vitamin } \mathrm{D}_{3} \text { oral supplementation }(50000 \mathrm{IU} \\
\text { weekly) intervention for } 12 \text { weeks improve vitamin } \\
\mathrm{D} \text {, MNSI (Michigan Neuropathy Screening } \\
\text { Instrument) ( } \mathrm{p} \text { value }<0.001 \text { ). }\end{array}$ \\
\hline $\begin{array}{l}\text { Karonova, et al, } \\
2020^{11}\end{array}$ & $\begin{array}{l}\text { Random, open } \\
\text { label }\end{array}$ & $\begin{array}{l}\text { Sixty-seven patients with T2DM and } \\
\text { peripheral neuropathy }\end{array}$ & $\begin{array}{l}\text { In individuals with T2DM with peripheral } \\
\text { neuropathy, large dose of cholecalciferol } \\
\text { around } 40,000 \text { IU/week for } 6 \text { months was linked to } \\
\text { improvements in clinical manifestations and } \\
\text { systemic inflammation. }\end{array}$ \\
\hline
\end{tabular}

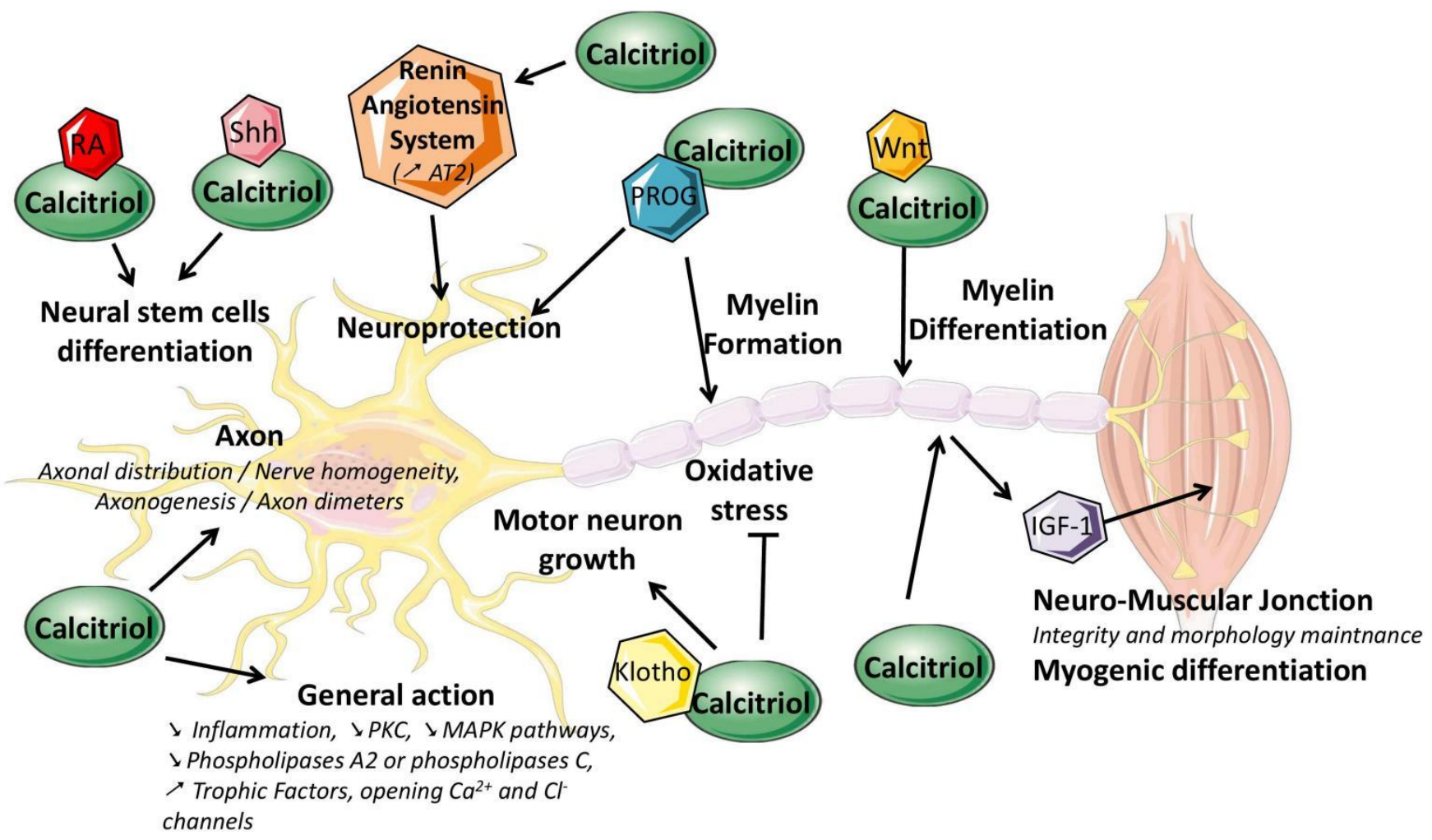

Figure 1. The function of calcitriol in the nervous system development. ${ }^{20}$

Some studies mentioned the benefit of oral supplementation of vitamin D3 is linked to a reduction in diabetic neuropathic signs and indications as well as an increase in vitamin D levels in the blood. ${ }^{10,11}$

The data are limited in study size and methodology. Most studies are lacking active study comparators and had limited data in therapeutic dosage to substantiate the effectiveness of vitamin D intake in the treatment of DPN symptoms. This narrative review aimed to discuss the unmet needs in the pharmacological management of neuropathic pain. We discuss the potential role of oral Vitamin D as an add-on pharmacological treatment for painful neuropathy.

\section{Methods}

We systematically search the studies about Vitamin D for the treatment of painful diabetic neuropathic condition. We 
used PubMed, Cochrane, Clinical Key, and Google Scholar for papers that used vitamin D phrases and painful diabetic neuropathy as our major database for this review. The keywords used in the research process include: diabetic neuropathic pain, Vitamin D, treatment. We mainly focus on the studies with either clinical studies, quasiexperimental, and Randomized Controlled Trial Design. The studies with the available full text and published in English/ Indonesian language will be review further. We make a systematic table to explain our review.

\section{Discussion}

Our review showed the potential benefit of Vitamin D for painful diabetic neuropathy. Painful diabetic neuropathic pain is one of the most common types of neuropathic pain. ${ }^{1}$ Patients with painful diabetic neuropathic pain are difficult to control, given current breakthroughs and knowledge in the discovery of pain-generating pathways. ${ }^{7}$ Only around half of afflicted individuals receive substantial clinical improvement from currently known symptomatic adjuvant pharmaceutical therapy, which are further restricted by side responses such as sleepiness and dizziness. ${ }^{7}$

Recent reviews on diabetic neuropathic pain imply that only a small percentage of patients get a satisfactory responses to medication treatment. ${ }^{4}$ Only one-third of diabetic painful neuropathic pain patients achieved satisfying pain relief. ${ }^{3}$ In most cases, total pain relief is not possible; related to the poor quality of life. ${ }^{2,4}$ The treatment that can interfere with the progressing damage of the nerve is very limited..$^{5,7}$

Vitamin D [25-hydroxyvitamin D, 25(OH) D] deficiency is a very usual diabetic. ${ }^{10}$ The low levels have been linked with to sensory neuropathy's existence and intensity. ${ }^{9,10}$ Table 1 showed the previous studies about the potential roles of vit $\mathrm{D}$ for painful diabetic neuropathy.

Vitamin D deficiencies are related with the severity of neuropathy in diabetes. According to an Indonesian research, people with severe neuropathic had vit D levels of $13.356 .20 \mathrm{ng} / \mathrm{mL}$, people with intermediate neuropathic had a vit D levels of $16.256 .08 \mathrm{ng} / \mathrm{mL}$, while people with mild neuropathic had a vit D levels of $198.85 \mathrm{ng} / \mathrm{mL}$. The Spearman correlation test yielded a $r$ value of -0.439 $(\mathrm{p}=0.001){ }^{16}$

Vitamin D supplementation is necessary for diabetic neuropathy patients since it promotes the synthesis of neurotrophins and neurotransmitters. ${ }^{17}$ Vitamin D phenotypes in nociceptive calcitonin gene associated peptide (CGRP) + neuron is unique, with hormonally regulated ligand and receptors values, implying a mechanistic link among neuropathic pain and vit $\mathrm{D}^{17,18}$

The possible interplay among vitamin $\mathrm{D}$, its receptor (VDR), and identified particular pain signaling pathways such as opioid receptors, epidermal growth factor receptor (EGFR), glial-derived neurotrophic factor (GDNF), and nerve growth factor (NGF) could explain how vitamin D exerts its analgesic activity at the stage of dorsal root ganglion (DRG) neurons. ${ }^{18,19}$

In the figure 1 explained the role of calcitriol in the nervous system, specifically in the nerve cell myelination and differentiation. Calcitriol controls and play role in the peripheral nervous system through a number of mechanisms, including the Renin Angiotensin System, Klotho, Sonic hedgehog (Shh), Wnt signaling pathway as well as the probable role of progesterone in stimulating calcitriol's differentiating impacts. ${ }^{20}$

Previous in vivo and in vitro research study on pain models revealed possible relations. Such research might point to vitamin D's potential for treating chronic pain, both alone or in conjunction with conventional analgesics. ${ }^{21}$ Vitamin D improves diabetic neuropathic pain through a variety of mechanisms: impacting some inflammatory pathways linked to the evolution and perseverance of chronic pain, decrease neutrophil function, inhibits nitric oxide synthase synthesis, affects prostaglandin action, rises neurotrophin synthesis, and modulates brain neurotransmitters. ${ }^{19,21}$ Further trials with larger study subjects are needed to confirm the beneficial effects of vitamin D. Vitamin D showed promising effects in neuropathy and pain in the clinical studies.

\section{Conclusion}

To summarize, vitamin D has a successful potential role in the treatment of diabetic neuropathic pain, but further research with more reliable approaches is necessary to assess the optimum dose, treatment method, and period.

\section{Conflic of Interest}

The authors report no conflicts of interest in this work.

\section{Acknowledgement}

The author thanks to Neurology Department, Duta Wacana Christian University School of Medicine and Bethesda Hospital for facilitating this research

\section{References}

1. Juster-Switlyk K, \& Smith AG. Updates in diabetic peripheral neuropathy. F1000Research, 5, F1000 Faculty Rev-738; 2016.

DOI: https://doi.org/10.12688/f1000research.7898.1

2. Iqbal Z, Azmi S, Yadav R, Ferdousi M, Kumar, M, Cuthbertson DJ, et al. Diabetic peripheral neuropathy: Epidemiology, diagnosis, and pharmacotherapy. Clinical Therapeutics; 2018. 40(6):828-849.

DOI: https://doi:10.1016/j.clinthera.2018.04.001

3. Schreiber AK, Nones CF, Reis RC, Chichorro, JG, Cunha JM. Diabetic neuropathic pain: Physiopathology and treatment. World journal of diabetes; 2015. 6(3):432-444.

DOI: https://doi.org/10.4239/wjd.v6.i3.432

4. Kaur S, Pandhi P, Dutta P. Painful diabetic neuropathy: An update. Annals of neurosciences; 2011. 18(4):168-175.

DOI: https://doi.org/10.5214/ans.0972-7531.1118409

5. Javed S, Alam U, Malik RA. Treating diabetic neuropathy: Present strategies and emerging solutions. The review of diabetic studies; 2015. 12(1-2):63-83. DOI: https://doi.org/10.1900/RDS.2015.12.63

6. Snyder MJ, Gibbs LM, Lindsay TJ. Treating painful diabetic peripheral neuropathy: An Update. American 
Family Physician; 2016. 94(3):227-234. Avalaible from: https://pubmed.ncbi.nlm.nih.gov/27479625/

7. Rosenberger DC, Blechschmidt V, Timmerman H, Wolff A, Treede RD. Challenges of neuropathic pain: Focus on diabetic neuropathy. Journal of Neural Transmission; 2020. 127(4):589-624. DOI: https://doi.org/10.1007/s00702-020-02145-7

8. Oraby MI, Srie MA, Abdelshafy S, Elfar E. Diabetic peripheral neuropathy: The potential role of vitamin D deficiency. Egypt J Neurol Psychiatry Neurosurg; 2019. 55:10. DOI: https://doi.org/10.1186/s41983019-0058-y

9. Sari A, Akdoğan Altun Z, Arifoglu Karaman C, Bilir Kaya B, Durmus B. Does vitamin d affect diabetic neuropathic pain and balance? J Pain Res; 2020. 13:171-179.

DOI: https://doi.org/10.2147/JPR.S203176

10. Alam U, Arul-Devah V, Javed S, Malik RA. Vitamin $\mathrm{D}$ and diabetic complications: True or False Prophet? Diabetes Ther; 2016. 7(1):11-26.

DOI: $10.1007 / \mathrm{s} 13300-016-0159-\mathrm{x}$

11. Karonova T, Stepanova A, Bystrova A, Jude EB. High-dose vitamin d supplementation improves microcirculation and reduces inflammation in diabetic neuropathy patients. Nutrients; 2020. Aug 20;12(9):2518. DOI: 10.3390/nu12092518

12. Shehab D, Al-Jarallah K, Abdella N, Mojiminiyi OA, Al Mohamedy H. Prospective evaluation of the effect of short-term oral vitamin $\mathrm{d}$ supplementation on peripheral neuropathy in type 2 diabetes mellitus. Med Princ Pract; 2015. 24(3):250-256.

DOI: $10.1159 / 000375304$

13. Alam U, Fawwad A, Shaheen F, Tahir A, Basit A, Malik RA, Improvement in neuropathy specific quality of life in patients with diabetes after vitamin D supplementation. Journal of Diabetes Research; 2017. DOI: $10.1155 / 2017 / 7928083$

14. Nadi M, Marandi SM, Esfarjani F, Saleki M, Mohammadi M. The comparison between effects of 12 weeks combined training and vitamin d supplement on improvement of sensory-motor neuropathy in type 2 diabetic women. Adv Biomed Res; 2017. 6:55.

DOI : 10.4103/2277-9175.205528

15. Ghadiri-Anari A, Mozafari Z, Gholami S, Khodaei SA, Aboutorabi-Zarchi M, Sepehri F, et al. Dose vitamin D supplementations improve peripheral diabetic neuropathy? A before-after clinical trial. Diabetes Metab Syndr; 2019. Jan-Feb;13(1):890-893. DOI: 10.1016/j.dsx.2018.12.014. Ep

16. Pinzon, RT, Gelgel PCS. The correlation between vitamin D deficiency and the severity of painful diabetic neuropathy in patients with type 2 diabetes mellitus (T2DM). Jurnal Gizi Klinik Indonesia, [S.1]; 2020 p. $9-14$.

DOI: https://doi.org/10.22146/ijcn.53924

17. Lee $\mathrm{P}$, Chen R. Vitamin D as an analgesic for patients with type 2 diabetes and neuropathic pain. Arch Intern Med; 2008. Apr 14;168(7):771-2. DOI: 10.1001/archinte.168.7.771. PMID: 18413561.

18. Basit A, Basit KA, Fawwad A, Shaheen F, Fatima N, Petropoulos IN, et al. Vitamin D for the treatment of painful diabetic neuropathy. BMJ Open Diabetes Res Care; 2016. Feb 10;4(1):e000148. DOI: 10.1136/bmjdrc-2015-000148.

19. Shipton EA, Shipton EE. Vitamin D and pain: Vitamin D and its role in the aetiology and maintenance of chronic pain states and associated comorbidities. Pain Res Treat; 2015.

DOI: $10.1155 / 2015 / 904967$.

20. Faye PA, Poumeaud F, Miressi F, Lia AS, Demiot C, Magy L, et al. Focus on 1,25-Dihydroxyvitamin D3 in the peripheral nervous system. Front Neurosci; 2019. Apr 12;13:348. DOI: 10.3389/fnins.2019.00348. PMID: 31031586; PMCID: PMC6474301.

21. Habib AM, Nagi K, Thillaiappan NB, Sukumaran V, Akhtar S. Vitamin D and its potential interplay with pain signaling pathways. Front Immunol; 2020. 11:820. Published 2020 May 28.

DOI: $10.3389 /$ fimmu.2020.00820 